\title{
Modeling temperature- and Cav3 subtype-dependent alterations in T-type calcium channel mediated burst firing
}

\author{
Fernando R. Fernandez ${ }^{1}$, Mircea C. Iftinca ${ }^{3,4}$, Gerald W. Zamponi ${ }^{3,45^{*}}$ (D) and Ray W. Turner $2,4,5^{*}$
}

\begin{abstract}
T-type calcium channels are important regulators of neuronal excitability. The mammalian brain expresses three T-type channel isoforms (Cav3.1, Cav3.2 and Cav3.3) with distinct biophysical properties that are critically regulated by temperature. Here, we test the effects of how temperature affects spike output in a reduced firing neuron model expressing specific Cav3 channel isoforms. The modeling data revealed only a minimal effect on baseline spontaneous firing near rest, but a dramatic increase in rebound burst discharge frequency for Cav3.1 compared to Cav3.2 or Cav3.3 due to differences in window current or activation/recovery time constants. The reduced response by Cav3.2 could optimize its activity where it is expressed in peripheral tissues more subject to temperature variations than Cav3.1 or Cav3.3 channels expressed prominently in the brain. These tests thus reveal that aspects of neuronal firing behavior are critically dependent on both temperature and T-type calcium channel subtype.
\end{abstract}

Keywords: Cav3,T-type, Calcium channel, Rebound burst discharge, Temperature

It is well established T-type calcium channels are important regulators of neuronal firing behavior [1, 2], whereas aberrant T-type channel activity can lead to disorders such as absence seizures and chronic pain [3]. T-type channels are thus considered important pharmacological targets for neurological disorders [3]. The mammalian genome expresses three different T-type channel isoforms (Cav3.1, Cav3.2 and Cav3.3) with distinct distributions in different neuronal populations and unique biophysical and pharmacological characteristics [4-6]. It has been suggested that Cav3 isoforms contribute differentially to the regulation of neuronal excitability [5-8]. Most modeling work is derived from biophysical parameters obtained at room temperature. Our previous

\footnotetext{
*Correspondence: zamponi@ucalgary.ca; rwturner@ucalgary.ca

2 Department of Cell Biology and Anatomy, Cumming School of Medicine University of Calgary, Calgary, Canada

${ }^{3}$ Department of Physiology and Pharmacology, Cumming School of Medicine University of Calgary, Calgary, Canada

Full list of author information is available at the end of the article
}

work revealed that the gating characteristics of T-type channels are strongly temperature dependent [9]. While Cav3.1 and Cav3.3 channels are expressed predominantly in the brain where temperature fluctuations are small, Cav3.2 channels are also expressed in sensory nerve endings in the skin where they are exposed to much greater temperature variations [3]. It is thus important to determine how different Cav3 isoforms may regulate firing properties of neurons at physiological temperatures. To understand the temperature-dependence of $\mathrm{Ca}_{v} 3$ kinetics for neuronal output, we built a reduced firing model neuron incorporating the biophysical characteristics of T-type calcium current $\left(I_{\text {CaT }}\right)$ recorded at $21^{\circ} \mathrm{C}$ or $37^{\circ} \mathrm{C}$ in our previous study [9] (see Additional file 1).

Additional file 2: Fig. S1 shows that the insertion of $I_{C a T}$ into the model had different effects on steady-state firing frequency depending on the $\mathrm{Ca}_{\mathrm{v}} 3$ subtype and recording temperature. At $37^{\circ} \mathrm{C}$ there was a small decrease in resting firing frequency for each of the Cav3 isoforms compared to $21^{\circ} \mathrm{C}$ (Additional file 2: Fig. S1A-C). However,

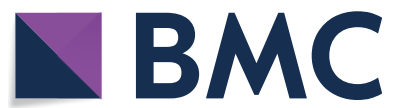

(c) The Author(s) 2021. Open Access This article is licensed under a Creative Commons Attribution 4.0 International License, which permits use, sharing, adaptation, distribution and reproduction in any medium or format, as long as you give appropriate credit to the original author(s) and the source, provide a link to the Creative Commons licence, and indicate if changes were made. The images or other third party material in this article are included in the article's Creative Commons licence, unless indicated otherwise in a credit line to the material. If material is not included in the article's Creative Commons licence and your intended use is not permitted by statutory regulation or exceeds the permitted use, you will need to obtain permission directly from the copyright holder. To view a copy of this licence, visit http://creativecommons.org/licenses/by/4.0/. The Creative Commons Public Domain Dedication waiver (http://creativeco mmons.org/publicdomain/zero/1.0/) applies to the data made available in this article, unless otherwise stated in a credit line to the data. 

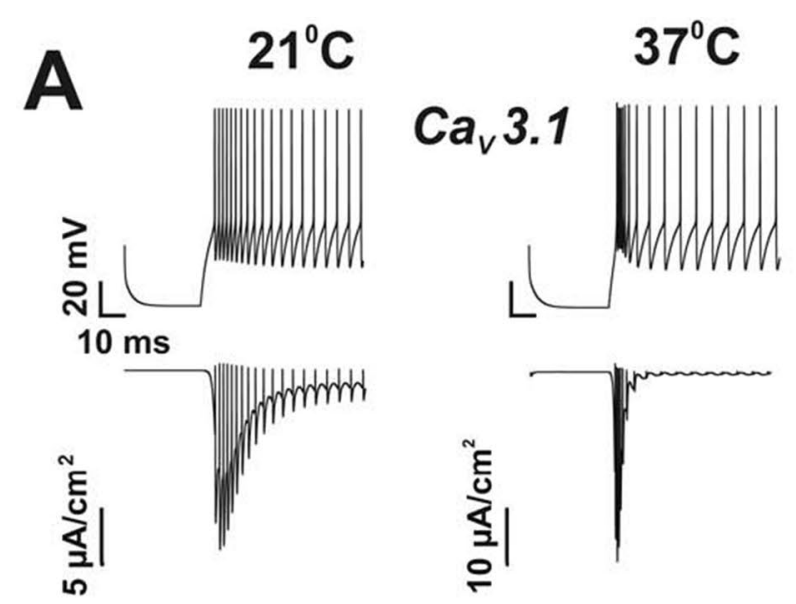

D

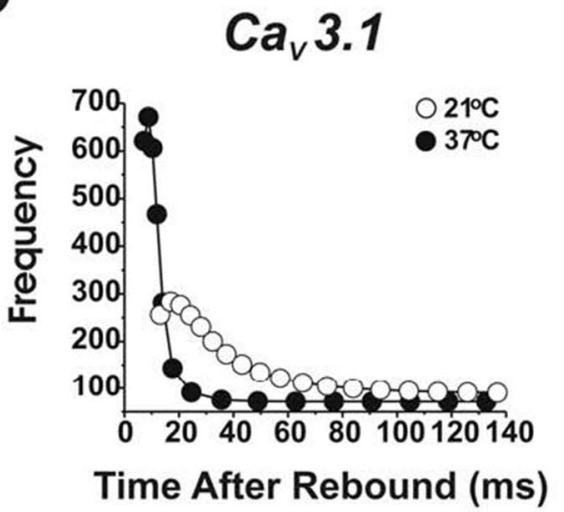

B

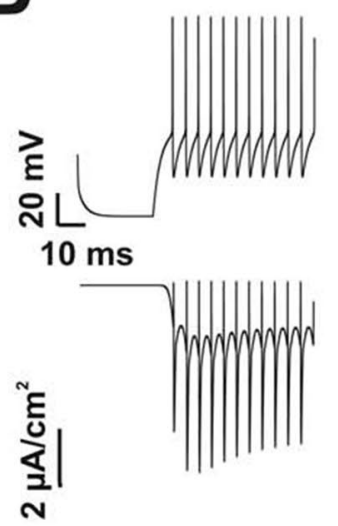

$\mathrm{Ca}_{v} 3.2$

E

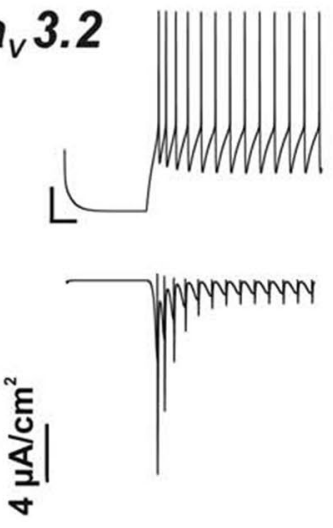

$\mathrm{Ca}_{v} 3.2$

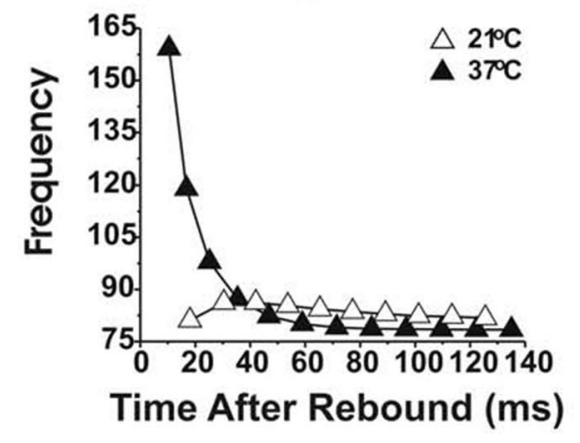

C
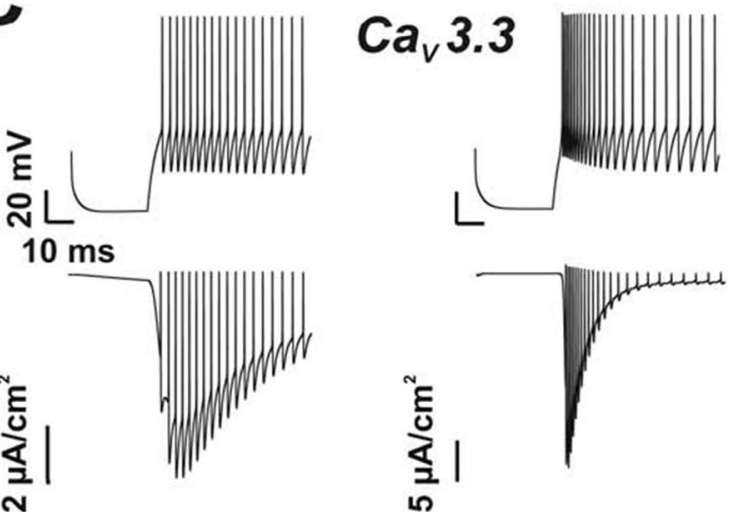

둥

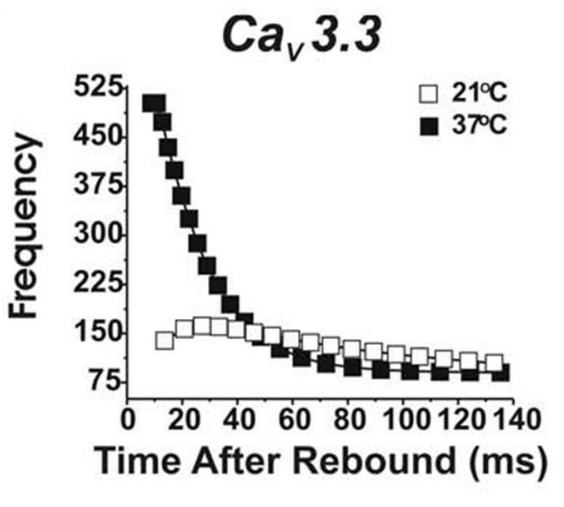

Fig. 1 Effects of $I_{C a T}$ in the model neuron on rebound depolarizations. For each isoform at the two temperatures the model was hyperpolarized $\left(-5 \mu \mathrm{A} / \mathrm{cm}^{2}\right)$ for $70 \mathrm{~ms}$ and then depolarized to $3 \mu \mathrm{A} / \mathrm{cm}^{2}$ to assess the effects of a transient increase in $\mathrm{I}_{\mathrm{CaT}}$ on firing frequency. A-C Neuronal output (top traces) and corresponding inward $\mathrm{I}_{\mathrm{CaT}}$ Current trajectories (lower traces) at the two temperatures for the three $\mathrm{Ca}_{v} 3$ isoforms. In the right panels (D-F) the firing frequencies are plotted as a function of the time since the end of the hyperpolarization for each of the three isoforms at both temperatures. Because these data were derived from mathematical modeling, no error bars are included 
inserting $I_{C a T}$ into the model greatly increased the ability to generate rebound spike firing following a $70 \mathrm{~ms}$ membrane hyperpolarization (Fig. 1). The principal determinant of the duration of burst firing was the inactivation time constant of $I_{\mathrm{CaT}}$. At $37^{\circ} \mathrm{C}$ we noted a faster rise to peak in spike frequency during rebound discharge, but also a faster decline back to steady-state frequency for all three channel subtypes (Fig. $1 \mathrm{~A}-\mathrm{C}$, top traces). An increase in temperature from 21 to $37^{\circ} \mathrm{C}$ also increased channel conductance and sped the kinetics of activation and inactivation. The changes in firing frequency closely matched the time course of $I_{C a T}$, which had faster overall activation and inactivation rates for all three $\mathrm{Ca}_{\mathrm{v}} 3$ isoforms (Fig. 1A-C, lower traces) at $37{ }^{\circ} \mathrm{C}$. Modeling Cav3.1 expression produced the sharpest increase in rebound burst at $21{ }^{\circ} \mathrm{C}$ (Fig. 1A, D) compared to only a small rebound burst for $\mathrm{Ca}_{\mathrm{v}} 3.2$ (Fig. 1B, E). This occurred because $\mathrm{Ca}_{\mathrm{v}} 3.2$ had a combination of slow time constants for activation and recovery from inactivation, especially relative to $\mathrm{Ca}_{\mathrm{v}} 3.1$. $\mathrm{Ca}_{\mathrm{v}} 3.3$ also produced a burst response that was faster and of higher frequency than $\mathrm{Ca}_{\mathrm{v}} 3.2$ because of a larger window current at $21{ }^{\circ} \mathrm{C}$. The major limiting factor to a contribution by $\mathrm{Ca}_{\mathrm{v}} 3.2$ and $\mathrm{Ca}_{\mathrm{v}} 3.3$ to rebound firing at $21{ }^{\circ} \mathrm{C}$ was a slow recovery from inactivation, which prevented the current from fully recovering during the preceding $70 \mathrm{~ms}$ hyperpolarizing step.

Increasing the temperature to $37{ }^{\circ} \mathrm{C}$ increased the peak frequency during a rebound burst for all three Cav3 isoforms (Fig. 1A-C). The rate of decrease in firing frequency during the rebound (Fig. 1D-F) was clearly linked to the time course of inactivation of the underlying $I_{C a T}$ (Fig. $1 \mathrm{~A}-\mathrm{C}$, lower traces). Furthermore, $\mathrm{Ca}_{\mathrm{v}} 3.1$ and $\mathrm{Ca}_{\mathrm{v}} 3.3$ had much larger peak firing frequencies during rebound bursting using the parameters measured at $37{ }^{\circ} \mathrm{C}$ than $\mathrm{Ca}_{\mathrm{v}} 3.2$ because of faster recovery time constants. Thus, $\mathrm{Ca}_{\mathrm{v}} 3.2$ had the least temperature sensitive recovery time constant of the three subtypes, as reflected in its poor ability to change firing frequency following hyperpolarization.

Our results suggest that all three $\mathrm{Ca}_{\mathrm{v}} 3$ isoforms may contribute to rebound depolarizations given the kinetics measured in the HEK cell expression system. Furthermore, the exact spike discharge characteristics elicited during the rebound depolarization may be regulated by the expression of specific $\mathrm{Ca}_{\mathrm{v}} 3$ subtypes [8]. Indeed, a comparison across cell types in cerebellum recorded in vitro revealed that rebound discharge capability was most prominent in cells that expressed the Cav3.1 isoform [8, 10-12]. It has however been difficult to unequivocally attribute a role of T-type channel isoforms to burst activity due to a lack of subtype specific T-type channel inhibitors [13]. Our modeling data provide insights into how individual calcium channel isoforms can regulate neuronal firing behavior according to kinetic parameters and conductance at physiological temperatures.

Our results complement previous data derived from models of thalamic neurons that replaced the biophysical characteristics of native thalamic neuron T-type current(s) with those of T-type isoforms near room temperature to test their contribution to rebound discharge [5, 6]. In Chemin et al. [5], normal thalamic neuron output was most closely mimicked when the native current was substituted with the kinetics of the expressed $\mathrm{Ca}_{\mathrm{v}} 3.1$ current, consistent with the finding that rebound discharge in these cells is abolished by knocking out the $\mathrm{Ca}_{v} 3.1$ gene [14]. However, substitution of any of the three isoforms enabled some type of spike discharge during the rebound depolarization. In contrast, McRory et al. [6] found that none of the expressed $\mathrm{Ca}_{\mathrm{v}} 3$ kinetics adequately substituted for the native thalamic T-type current, and only $\mathrm{Ca}_{\mathrm{v}} 3.3$ was able to generate a rebound burst discharge. Given the marked dependence of rebound burst discharge on the holding potential and the amplitude and duration of the hyperpolarizing stimulus, it is possible that the model of McRory et al. [5] was not optimized to produce burst firing, particularly with respect to the size of window currents.

As with all models, there are several caveats that cannot be ignored. First, alternate splicing of T-type channels can affect their biophysical characteristics [15], in a manner that could contribute differently to neuronal firing. Second, since most neurons express more than one $\mathrm{Ca}_{\mathrm{v}} 3$ isoform we cannot predict how this might affect the overall neuronal output. Third, we acknowledge that gating characteristics of sodium and potassium channels may also be temperature dependent, but were kept constant in the model. Finally, we reiterate that our model provides only a snapshot of a particular set of experimental conditions, and should be considered a tool that allows one to compare the relative abilities of different $\mathrm{T}$ type isoforms to affect firing properties. Nonetheless, our data indicate that T-type channel isoforms differ in their propensities to alter firing rates in neurons in a temperature-dependent manner.

\section{Abbreviation \\ I $_{\text {Ca: }}$ T-type calcium current.}

\section{Supplementary Information}

The online version contains supplementary material available at https://doi. org/10.1186/s13041-021-00813-7.

Additional file 1. Mathematical modeling. This file describes the mathematical model used to generate Fig. 1.

Additional file 2: Fig. S1. Effects of $I_{\text {CaT }}$ on steady-state firing frequency in a model neuron. 


\section{Acknowledgements \\ Not applicable.}

\section{Authors' contributions}

FRF constructed the firing model, MI generated experimental data, GWZ and RWT conceived and supervised the study. FRF, GWZ and RWT wrote the manuscript. All authors read and approved the final manuscript.

\section{Funding}

This work was supported by the Canadian Institutes of Health Research (RWT, GWZ). GWZ holds a Canada Research Chairs, Government of Canada.

\section{Availability of data and materials}

All data generated or analyzed during this study are included in this published article and in our previously published work [9].

\section{Declarations}

Ethics approval and consent to participate

Not applicable.

\section{Consent for publication}

Not applicable.

\section{Competing interests}

The authors declare no competing interests.

\section{Author details}

'Department of Biomedical Engineering, Boston University, Boston, MA, USA. ${ }^{2}$ Department of Cell Biology and Anatomy, Cumming School of Medicine University of Calgary, Calgary, Canada. ${ }^{3}$ Department of Physiology and Pharmacology, Cumming School of Medicine University of Calgary, Calgary, Canada. ${ }^{4}$ Hotchkiss Brain Institute, University of Calgary, Calgary, Canada. ${ }^{5}$ Alberta Children's Hospital Research Institute, University of Calgary, Calgary, Canada.

Received: 21 May 2021 Accepted: 18 June 2021

Published online: 17 July 2021

\section{References:}

1. Huguenard JR. Low-threshold calcium currents in central nervous system neurons. Annu Rev Physiol. 1996;58:329-48.

2. Coulter DA, Huguenard JR, Prince DA. Calcium currents in rat thalamocortical relay neurones: kinetic properties of the transient, low-threshold current. J Physiol. 1989:414:587-604.
3. Zamponi GW. Targeting voltage-gated calcium channels in neurological and psychiatric diseases. Nat Rev Drug Discov. 2016;15:19-34.

4. Perez-Reyes E. Molecular physiology of low-voltage-activated t-type calcium channels. Physiol Rev. 2003;83:117-61.

5. Chemin J, Monteil A, Perez-Reyes E, Bourinet E, Nargeot J, Lory P. Specific contribution of human T-type calcium channel isotypes (alpha(1G), alpha(1H) and alpha(1I)) to neuronal excitability. J Physiol. 2002;540:3-14.

6. McRory JE, Santi CM, Hamming KS, Mezeyova J, Sutton KG, Baillie DL, Stea A, Snutch TP. Molecular and functional characterization of a family of rat brain T-type calcium channels. J Biol Chem. 2001;76:3999-4011.

7. Cain SM, Snutch TP. Contributions of T-type calcium channel isoforms to neuronal firing. Channels (Austin). 2010;4:475-82.

8. Molineux ML, McRory JE, McKay BE, Hamid J, Mehaffey WH, Rehak R, Snutch TP, Zamponi GW, Turner RW. Specific T-type calcium channel isoforms are associated with distinct burst phenotypes in deep cerebellar nuclear neurons. Proc Natl Acad Sci USA. 2006;103:5555-60.

9. Iftinca M, McKay BE, Snutch TP, McRory JE, Turner RW, Zamponi GW. Temperature dependence of T-type calcium channel gating. Neuroscience. 2006;142:1031-42.

10. Swensen AM, Bean BP. Ionic mechanisms of burst firing in dissociated Purkinje neurons. J Neurosci. 2003;23:9650-63.

11. Engbers JD, Anderson D, Tadayonnejad R, Mehaffey WH, Molineux ML, Turner RW. Distinct roles for I(T) and I(H) in controlling the frequency and timing of rebound spike responses. J Physiol. 2011;589:5391-413. https:// doi.org/10.1113/jphysiol.2011.215632

12. Dykstra S, Engbers JD, Bartoletti TM, Turner RW. Determinants of rebound burst responses in rat cerebellar nuclear neurons to physiological stimuli. J Physiol. 2016;594(4):985-1003. https://doi.org/10.1113/JP271894.

13. Snutch TP, Zamponi GW. Recent advances in the development of T-type calcium channel blockers for pain intervention. Br J Pharmacol. 2018;175:2375-83.

14. Kim D, Song I, Keum S, Lee T, Jeong MJ, Kim SS, McEnery MW, Shin HS. Lack of the burst firing of thalamocortical relay neurons and resistance to absence seizures in mice lacking alpha (1G) T-type $\mathrm{Ca}(2+)$ channels. Neuron. 2001;31:35-45.

15. Chemin J, Monteil A, Bourinet E, Nargeot J, Lory P. Alternatively spliced alpha $(1 \mathrm{G})(\mathrm{Ca}(\mathrm{V}) 3.1)$ intracellular loops promote specific T-type $\mathrm{Ca}(2+)$ channel gating properties. Biophys J. 2001;80:1238-50.

\section{Publisher's Note}

Springer Nature remains neutral with regard to jurisdictional claims in published maps and institutional affiliations.
Ready to submit your research? Choose BMC and benefit from:

- fast, convenient online submission

- thorough peer review by experienced researchers in your field

- rapid publication on acceptance

- support for research data, including large and complex data types

- gold Open Access which fosters wider collaboration and increased citations

- maximum visibility for your research: over 100M website views per year

At BMC, research is always in progress.

Learn more biomedcentral.com/submissions 